\title{
DWUTOROWY WPŁYW PÓŁNOCNO-ZACHODNIEGO POGRANICZA INDII BRYTYJSKICH NA BRYTYJSKĄ WIZJĘ IMPERIUM NA PRZEŁOMIE XIX I XX WIEKU
}

\author{
Benedykt Żurek \\ Uniwersytet Jagielloński w Krakowie
}

(1) http://orcid.org/0000-0002-6896-1065

\begin{abstract}
THE DUAL IMPACT OF BRITISH INDIA'S NORTH-WEST FRONTIER ON THE BRITISH IMPERIAL IDEA AT THE TURN OF THE $20^{\text {TH }}$ CENTURY

The article presents the dual impact of British India's North-West Frontier on the British idea of empire. The Frontier was an imperial myth - the special interpretation of the past - which provided a pattern of behavior that should be followed by British imperial soldiers and officials. The myth itself was propagated by war correspondents and writers, such as Rudyard Kipling, but the Frontier also served as an "imperial laboratory" for a new generation of military technocrats (e.g. Charles Callwell) who could develop and describe their outlook on asymmetric warfare. The new approach to so-called small wars was a local variant of the general changes in military organization that occurred in the second half of the 19th century.
\end{abstract}

Keywords: frontier, British India, asymmetric warfare, myth, empire.

Słowa klucze: pogranicze, Indie Brytyjskie, konflikt asymetryczny, mit, imperium.

Północno-Zachodnie Pogranicze Indii Brytyjskich było specyficznym obszarem dawnego imperium brytyjskiego. Położone na jego rubieżach, przez długi czas pozbawionych dobrego połączenia komunikacyjnego i większego zainteresowania ze strony rządu w Kalkucie/Simli, wywarło jednak ogromny wpływ ideowy na brytyjską wizję imperium. Ów wpływ nie był jednoznaczny. Pod koniec czasów wiktoriańskich i na początku edwardiańskich oddziaływał on na brytyjskie elity imperialne przez dwa równoległe i na pierwszy rzut oka wykluczające się kanały, z których pierwszy można nazwać „idealistycznym”, a drugi „technokratycznym”. 
Z jednej strony Pogranicze stanowiło imperialny mit Wielkiej Brytanii, pożywkę dla ludzi pióra sławiących w swych utworach męstwo i honor służących tam brytyjskich oficerów i żołnierzy. Z drugiej strony stało się ono także pewnym laboratorium, gdzie testowano nowe, „technokratyczne” podejście do wojny. Można powiedzieć, że koncepcja small wars to lokalna mutacja ogólnych zmian, jakie na przełomie XIX i XX wieku zachodziły w brytyjskiej armii. Wizja Pogranicza w pracach kapitana Charlesa Callwella i jemu podobnych znacznie różniła się od literackich fantazji Rudyarda Kiplinga. Wspomniane postacie są pewnymi archetypami dwóch sposobów percepcji Pogranicza wśród brytyjskiej elity imperialnej.

Celem artykułu jest, po pierwsze, próba odpowiedzi na pytanie, na czym polegał ten mit, w jaki sposób został wykreowany i jak oddziaływał na rzeczywistość, a po drugie - przedstawienie nowatorskiego podejścia do specyficznego typu wojny w kontekście imperialnej rubieży, jaką była północno-zachodnia granica na przełomie XIX i XX wieku.

Zanim jednak ów mit zostanie poddany analizie, trzeba krótko wyjaśnić pojęcia, których zrozumienie jest niezbędne do dalszego śledzenia wywodu, a więc przedstawić, czym są mit polityczny/historyczny i pamięć zbiorowa oraz dlaczego mity są zjawiskiem typowym i niezbędnym do formowania się tożsamości czy to narodowej, czy imperialnej. Należy się przyjrzeć roli samego Pogranicza w brytyjskim podejściu do spraw imperialnych oraz krótko przeanalizować fenomen small wars, czyli dokonać przeglądu wcześniejszych metod organizacji wojskowej na Pograniczu i umieścić te zmiany w szerszym kontekście metamorfozy, jaką brytyjska armia przeszła w czasach późnowiktoriańskich.

\section{POGRANICZE JAKO IMPERIALNY MIT WIELKIEJ BRYTANII}

Słownik języka polskiego definiuje słowo „mit” na trzy sposoby. Może to być: 1) fantastyczna historia, opowieść o bogach, demonach, legendarnych bohaterach i nadnaturalnych wydarzeniach, stanowiąca próbę wyjaśnienia odwiecznych zagadnień bytu, świata, życia i śmierci, dobra i zła oraz przeznaczenia człowieka; 2) ubarwiona wymyślonymi szczegółami historia o jakiejś postaci lub o jakimś wydarzeniu; 3) fałszywe mniemanie o kimś lub o czymś uznawane bez dowodu ${ }^{1}$.

Pierwsza z powyższych definicji jest chyba najbardziej popularna. Większość ludzi, gdy słyszy słowo „mit”, od razu ma przed oczami 12 prac Heraklesa lub walkę Tezeusza z Minotaurem. Definicje druga i trzecia bardziej oddają istotę tego, czym zamierzamy się zajmować w tym rozdziale. Można zatem powiedzieć, że mit to niemająca pokrycia $\mathrm{w}$ faktach wizją przeszłości, która $\mathrm{z}$ jakichś powodów pozostaje żywa w danej społeczności.

Encyklopedia polityczna podaje definicję mitu politycznego, a więc konkretnej odmiany ogólnie rozumianego mitu. Określa go jako „sposób narracji politycznej,

\footnotetext{
1 Stownik języka polskiego, t. 2, red. M. Szy mczak, Warszawa 1979, s. 187.
} 
którego celem nie jest racjonalne przekonanie do pewnych idei politycznych, ale wytworzenie zachowań instynktownych. [...] Mit polityczny jest formą idei politycznej odrzucającej rozumowanie i doświadczenie w poszukiwaniu prawdy w polityce na rzecz instynktownej wiary w jakieś twierdzenie dotyczące świata politycznego"2. Mit stanowi zatem przeciwieństwo wiedzy naukowej i ma na celu wytworzenie pewnego sposobu zachowania, a także myślenia o polityce.

Myślenie mityczne od myślenia historycznego odróżnia też koncepcja czasu. Myślenie mityczne opiera się na jego cykliczności, tj. wyobrażeniu o złotym wieku, znaczonym właściwymi postawami ludzkimi, ale utraconym na rzecz chaosu. Aby powrócić do złotego wieku, należy wskrzesić wartości przodków. Tylko tak można osiągnąć szczęście i pomyślność. Idea cykliczności czasu stoi w sprzeczności względem koncepcji linearnej, która odrzuca wizję złotego wieku na rzecz postępu ludzkości rozwijającej to, co pozostawiły poprzednie pokolenia, a nie poszukującej idealnego świata w przeszłości.

Mit jest elementem budującym pamięć zbiorową. Tę należy zaś zdefiniować jako „dynamiczny system wyobrażeń o przeszłości danej społeczności (o zaludniających ją postaciach, minionych wydarzeniach, jakie w niej zaszły) konstruowany przez jej członków z treści o zróżnicowanym charakterze i różnorodnej genezie, w toku procesu obejmującego złożone sekwencje społecznych interakcji, przebiegających zgodnie z ustalonymi społecznie i kulturowo regułami”’3. Pamięć zbiorowa dokonuje pewnej mitologizacji historii, polegającej na ,spontanicznym przekształcaniu postaci oraz wydarzeń z przeszłości w bezczasowe wzory i personifikacje wartości, które sankcjonują zachowania i postawy ważne dla życia zbiorowości"4.

„Pamięć zbiorowa” to zatem pewna teleologiczna interpretacja wydarzeń historycznych. Szczycąc się bohaterstwem ludzi w przeszłości, chce się pokazać, że taka postawa jest ciągle uznawana za właściwą dla członków danej społeczności. Pokazując $\mathrm{w}$ dobrym świetle wizje polityczne $\mathrm{z}$ minionych wieków (uproszczając je przez ukazanie tylko dobrych stron, przemilczając ich negatywne skutki), dokonuje się legitymizacji teraźniejszych koncepcji władzy i prowadzonej przez nią polityki zagranicznej. Na plan pierwszy wysuwa się tu emocjonalny stosunek do przeszłości, wyrastający z głęboko ludzkiej zdolności uczuciowego reagowania na otaczającą rzeczywistośćs.

O tym, które wydarzenia z przeszłości danej społeczności zostaną zmitologizowane, decyduje się w sposób subiektywny i selektywny. Ogromną rolę odgrywają tu ludzie pióra utrwalający pewne stereotypy na temat historii danego narodu. W średniowieczu byli to głównie kronikarze, trubadurzy i poeci, potem zaś szeroko rozumiani literaci, czyli historycy i pisarze.

2 A. Wielomski, Mit polityczny [w:] Encyklopedia polityczna, t. 1: Myśl polityczna: główne pojęcia, doktryny i formy ustroju, red. J. Bartyzel, B. Szlachta, A. Wielomski, Radom 2007, s. 227-228.

3 B. Szacka, Czas przeszly, pamięć, mit, Warszawa 2006, s. 19.

4 Eadem, Pamięć społeczna a identyfikacja narodowa [w:] Trudne sąsiedztwa. Z socjologii konfliktów narodowościowych, red. A. Jasińska-Kania, Warszawa 2001, s. 8.

5 Por. T. Biernat, Mit polityczny, Warszawa 1989, s. 95-96. 
Ponieważ nie da się na dłuższą metę sprawować władzy ani prowadzić polityki zagranicznej bez społecznego poparcia dla danych idei, mity odgrywają ważną rolę w oddziaływaniu na ludzi i kreowaniu pamięci zbiorowej. Przypomina się tu słynne orwellowskie zdanie z Roku 1984 - kto kontroluje przeszłość, ten kontroluje teraźniejszość, a kto kontroluje teraźniejszość, ten kontroluje przyszłość. Kontrola przeszłości odbywa się więc w dużej mierze przez kreowanie i podtrzymywanie żywotności pewnych mitów. One wpływają na to, jakie postawy w danej społeczności uznawane są za właściwe i jakie koncepcje polityczne zasługują na szacunek. Dzięki temu dokonuje się legitymizacji pewnych działań, które mają wpływ na to, jak będzie wyglądać przyszłość.

Dla podtrzymania żywotności mitu ważny jest proces jego aktualizacji. Odbywa się on przez uczestnictwo w pewnych rytuałach. Joseph Campbell uważa, że rytuał jest żywą inscenizacją mitu, a człowiek uczestniczący w micie staje się jednym z jego bohaterów ${ }^{6}$. Anna Siewierska-Chmaj słusznie zauważa, że „powtarzalność rytuału potwierdza stabilność i nieusuwalność społecznych wzorców, a jednocześnie przekreśla historyczność czasu. Rytuał łączy przeszłość, teraźniejszość i przyszłość, redukując napięcia towarzyszące procesowi przemijania"7. Mówiąc o rytuale politycznym, mamy na myśli parady wojskowe, uroczystości patriotyczne związane z rocznicami ważnych dla danej społeczności wydarzeń (np. zburzenie Bastylii we Francji czy Rememberance Sunday w Wielkiej Brytanii), które wzmacniają poczucie tożsamości i potwierdzają żywotność mitu.

Aktualizacja mitu politycznego odbywa się nie tylko przez uczestnictwo w danych rytuałach. Niemniej ważny wydaje się także proces kształtowania świadomości i charakterów młodego pokolenia. Ten dokonuje się w trakcie edukacji. Istotny jest zatem program, wedle którego naucza się w szkołach, i kanon lektur, z którymi winien zapoznać się każdy uczeń. Jeśli położy się nacisk na czytanie treści głoszących chwałę imperium, młode pokolenie przesiąknie słusznością idei imperialnej i będzie emocjonalnie przeżywać tę wizję jako ważny element swojej tożsamości. Jeśli zacznie się przedstawiać imperium jako narzędzie opresji i dominacji, młode pokolenie straci wiarę w słuszność podtrzymywania projektu imperialnego.

Mając to na uwadze, łatwiej dostrzec znaczenie twórczości pisarzy takich jak George Orwell, którzy w dwudziestoleciu międzywojennym dokonywali dekonstrukcji mitów imperialnych. Pokolenie pisarzy bogatszych o bolesne doświadczenia I wojny światowej miało bardziej krytyczne podejście do problemu imperium i jego roli w świecie. Oddziaływanie ich prac na kolejne generacje Brytyjczyków pozwoliło bez większego żalu rozmontować imperium. Skoro dźwiganie brzemienia białego człowieka nie stanowiło już wartości ani pożądanej, ani popularnej w Wielkiej Brytanii, jaki był cel utrzymywania zamorskich posiadłości? Kiplingowski Kim, dzielnie broniący Indii przed rosyjskimi szpiegami, przestał być wzorcem dla nastolatków na Wyspach.

6 J. Campbe11, Potega mitu. Rozmowy Billa Moyersa z Josephem Campbellem, thum. I. Kania, Kraków 1994, s. 136.

7 A. Siewierska-Chmaj, Mity w polityce. Funkcje i mechanizmy aktualizacji, Warszawa 2016, s. 69. 
Mając na względzie dalsze rozważania, w tym miejscu należy poświęcić nieco uwagi pewnemu rodzajowi mitu, jakim jest mit bohaterski. W większości przypadków jego narracja sprowadza się do przedstawienia herosa, który opuszcza swój świat i odchodzi gdzieś daleko, aby odnaleźć to, co jego lud utracił, a bez czego nie może powrócić ład. Bohater dzielnie stawia czoła przeciwnościom losu, odznacza się niebywałą odwagą, walczy z chaosem. Potem coś zakłada, na przykład nową religię lub nowe miasto, bądź kreuje nowy sposób życia ${ }^{8}$.

$\mathrm{W}$ przypadku znaczenia wątku bohaterskiego w micie pogranicza imperialnej Wielkiej Brytanii będziemy mieć do czynienia z nieco „uboższą” wersją tego mitu. Heros, urodzony w jakichś bezpiecznych regionach imperium, porzuca domowe pielesze, aby stawić czoła nieznanemu. Przybywa na Pogranicze, by tam walczyć na chwałę imperium. Jego zadaniem jest powstrzymanie barbarzyńskich rabusiów, rosyjskiej agresji, pokonanie własnych słabości, zdobycie sławy. Taki bohater nie zakłada nowej wspólnoty takiej jak naród, lecz kreuje nowy sposób życia, w którym niezbędnymi wartościami są honor, odwaga i niesienie brzemienia białego człowieka w służbie na rzecz imperium.

Ten bardzo sugestywny w swym przekazie i nacechowany silnymi emocjami obraz stanowi symbol męstwa i honoru. Iluż późniejszych imperialnych bohaterów patrzyło na malarskie dzieło Benjamina Westa? Czyż obraz umierającego generała Jamesa Wolfe'ego nie budzi chęci pomszczenia nieustraszonego żołnierza? Indianie i Europejczycy, wszyscy wiernie trwają przy konającym. Jego śmierć nie poszła jednak na marne. Ogromne połacie dawnej francuskiej Kanady zostały na mapie „pokolorowane" na czerwono. Poświęcenie się sprawie imperium jest walką na rzecz ojczyzny i hołdem, jaki każdy mężczyzna winien złożyć honorowi. W zamian czeka go nagroda - poczucie spełnionego obowiązku i nieśmiertelna chwała9.

$\mathrm{Z}$ czasem brytyjski mit bohaterski przybierze też nieco inną formę. Będzie nim motyw samotnego białego oficera, który gdzieś na końcu świata dzielnie stawia czoła hordom barbarzyńców. Wykorzystując potęgę swej inteligencji, niebywałe zdolności organizacyjne i autorytet, jakim cieszy się pośród garstki „swoich” nielicznych kolorowych żołnierzy, mężnie odpiera ataki wroga i czeka na odsiecz. Najsłynniejszym z takich przypadków jest oczywiście Charles Gordon, ale motyw ten powracał niejednokrotnie także w kontekście Pogranicza (np. w opisach oblężenia Czitralu w $1895 \mathrm{r}^{10}$ ). Ten typ mitu bohaterskiego różni się od swojej „klasycznej” odmiany tym, że nie wydarza się w pradawnych czasach, lecz współcześnie, za to w egzotycznych

8 J. Campbell, Bohater o tysiacu twarzy, thum. A. Jankowski, Kraków 2013, s. 21. Mit bohaterski w ujęciu antropologicznym przedstawiono w pracy: Ł. Trzciński, Mit bohaterski w perspektywie antropologii filozoficznej i kulturowej, Kraków 2006.

9 J. Paxman, Empire, London 2012, s. 38-39.

10 Por. W.G.L., Beynon, With Kelly to Chitral, London 1896; G.S. Robertson, Chitral: The Story of Minor Siege, London 1900; F.E. Younghusband, The Relief of Chitral, London 1895; H.C. Thomps on, The Chitral Campaign, London 1895. 
krainach ${ }^{11}$. Odległość czasu zastąpiona została odległością geograficzną, lecz motyw przewodni pozostaje ten sam.

Jak pisze wspomniana już Anna Siewierska-Chmaj, ,mity heroiczne mają wyjątkowo silny polityczny potencjał. Bohater symbolizuje pewien ustalony porządek społeczny, a jego historia pokazuje także antytezę - antyporządek, ustanawiając w ten sposób przestrzeń politycznego tabu. Heroiczny mit pełni funkcję nie tylko wychowawczą, wskazując wzór do naśladowania, ale także aksjonormatywną - wyznaczającą wartości i reguły postępowania dla całej grupy ${ }^{12}$ ".

Przez kreowanie odpowiednich wzorców mit pełni ważną funkcję w budowaniu tożsamości zbiorowej każdej społeczności. Stanowi zjawisko uniwersalne, gdyż dostrzec go można w doświadczeniu każdego narodu. Jest on sposobem legitymizacji pewnych form zachowania, zarówno jeśli chodzi o sprawujących władzę, którzy muszą realizować swoje wizje zgodnie z oczekiwaniami rządzonych przez siebie, jak również zwykłych ludzi, którzy powinni postępować zgodnie z przechowywanymi w pamięci zbiorowej mitami, aby nie naruszyć istniejącego w danej społeczności tabu.

Mit może być definiowany jako pewna forma postrzegania rzeczywistości przez daną grupę. Odnosząc pewne „mityczne” wyobrażenia danej społeczności wobec ich państwa/imperium, można doszukać się motywów podejmowania takich, a nie innych decyzji politycznych. Decyzja polityczna nie jest zawieszona w próżni, lecz w pewnym sensie stanowi wypadkową sposobu myślenia danej grupy o świecie i miejscu w nim własnego państwa.

Zjawisko mitologizacji historii to proces spontaniczny i selektywny. Część wydarzeń z przeszłości uzyskuje żywotność w pamięci zbiorowej, a część nie. Ważną rolę odgrywa proces aktualizacji mitów, albo przez uczestnictwo w pewnych rytuałach, albo zaznajamianie się z literaturą odwołującą się do mitów.

Równie istotna co proces mitologizacji przeszłości jest także jego odwrotność, czyli demitologizacja historii. Dokonuje się ona nie tylko na niwie naukowej, gdzie publikuje się prace rozprawiające się z mitami, ale także na gruncie czysto literackim, gdzie dawne mity się ośmiesza albo przedstawia ich drugie dno, podważając tym samym ich zasadność. Trzeba mieć jednak na uwadze, że niektóre mity są bardzo mocno zakorzenione w pamięci zbiorowej i nie tak łatwo je z niej wyrugować. Jest to raczej proces trwający przez pokolenia.

Późnowiktoriańscy piewcy brytyjskiego imperializmu często powoływali się na koncepcję samotnego człowieka silnej woli, który nadzoruje oddaloną od cywilizacji placówkę. Ich zdaniem warunkiem sine qua non realizacji imperialnego projektu była służba ludzi charakteryzujących się antycznymi cnotami: żelazną wolą, zdecydowaniem, umiejętnością kreatywnego myślenia, zimną krwią i silnymi mięśniami ${ }^{13}$. Uświadomienie sobie tego problemu pozwala dostrzec znaczenie funkcjonujących

11 J. MacKenzie, Heroic Myths of Empire [w:] Popular Imperialism and the Military, 1850-1950, Manchester 1980, s. 112-113.

12 A. Siewierska-Chmaj, op. cit., s. 190.

${ }^{13}$ E.T. Stokes, The Administrators and Historical Writings on India [w:] Historians of India, Pakistan and Ceylon, ed. H. Phillips, Oxford 1961, s. 391-392. 
w pamięci zbiorowej mitów i wyobrażeń odnoszących się do osób będących na służbie imperium. Imperialna szkoła charakterów nie powstała w próżni. Oddziaływała ona na ludzi, którzy przez nią przeszli, ale w pewnym sensie kreowana była też przez aprioryczne wyobrażenia o niej.

Imperium brytyjskie, jak każdy większy twór polityczny, miało swój zbudowany z mitów ideologiczny fundament. Dzięki niemu można było uzasadnić sens jego istnienia i usprawiedliwiać taką, a nie inną politykę imperialną. Oddający się służbie kolonialnej Brytyjczycy zapoznawali się z imperialnymi mitami w trakcie swojej edukacji na Wyspach. W takich kuźniach imperialnych kadr jak Eton czy Rugby i Oxbridge ${ }^{14}$ na późniejszym etapie kształcenia, wpajano im pewien etos, którego winni przestrzegać. Sam etos zaś tworzony był pod wpływem mitów.

W połowie XIX wieku pojawiła się koncepcja traktowania wojen kolonialnych na rubieżach imperium w kategoriach moralnych. Od czasów wojny krymskiej armia ukazywana jest nie jako narzędzie represji stosowane przeciwko klasie robotniczej, ale przede wszystkim jako zapora, która chroni cywilizację przed barbarzyństwem ${ }^{15}$. Myśliciel z tamtych czasów, John Ruskin, przedstawiał uczestników wojen kolonialnych jako swego rodzaju błędnych rycerzy, ciągle używających szlachetnej białej broni, zamiast coraz bardziej zaawansowanych technicznie narzędzi uśmiercania wroga ${ }^{16}$. Podobny schemat myślowy podzielał też Winston Churchill wychowywany $\mathrm{w}$ etosie wiktoriańskiego wojownika. W pamiętnikach daje on wyraz nostalgii za szlachetnymi metodami wojowania ${ }^{17}$. Znany badacz tematyki imperialnej John MacKenzie porównuje mechanizm działania imperialnych mitów do stosowanej przez Kościół Rzymskokatolicki praktyki kanonizacji1 ${ }^{18}$. W obu przypadkach chodzi o to samo - pokazanie wzorcowego sposobu postępowania.

W tym kontekście Pogranicze ze względu na swoją specyfikę jest najlepszym teatrem do obrony cywilizacji przed barbarzyństwem. Zamieszkane było przez wojownicze pasztuńskie plemiona, sąsiadowało z mającym ambiwalentny stosunek do Wielkiej Brytanii Afganistanem, a także mogło stanowić arenę powstrzymywania rosyjskiej inwazji, której widmo przez cały XIX wiek obecne było wśród odpowiedzialnych za Indie Brytyjczyków; wreszcie posiadało zapierającą dech w piersiach romantyczną scenerię gór, dolin i przełęczy. Częste od lat 90. XIX wieku walki z coraz lepiej zorganizowanymi Pasztunami sprawiały, że można tam było spotkać stanowiącego wyzwanie wroga i naprawdę urzeczywistnić bohaterski mit, walcząc $\mathrm{z}$ barbarzyństwem.

Ponieważ w wiktoriańskiej Anglii za ważne cechy uznawano honor i odwagę, okazanie tchórzostwa postrzegano jako naruszenie pewnego tabu. Aby zmazać swoje przewinienie, należało to jakoś odpokutować, pokazać, że była to chwilowa słabość

14 Zbitka słów powstała od Oxford i Cambridge, dwóch najbardziej prestiżowych brytyjskich uczelni, w których odbywała się edukacja brytyjskiej klasy imperialnej.

15 J. MacKenzie, Introduction [w:] Popular Imperialism and the Military, 1850-1950, ed. J. MacKenzie, Manchester 1980, s. 1.

16 Ibidem, s. 9.

17 W. Churchill, Moja młodość, tłum. T. Bieroń, Poznań 2000, s. 55-56.

18 J. MacKenzie, Introduction..., s. 15. 
i że można własnym postępowaniem przywrócić „porządek” w swoim życiu. Wątek ten podejmował między innymi Joseph Conrad w Lordzie Jimie. Tytułowy bohater tej powieści po ucieczce ze statku „Patna” szuka swojego odkupienia w Patusanie ${ }^{19}$.

W imperium brytyjskim decyzje polityczne podejmowała wąska elita, absolwenci Eton, Harrlow, Sandhurst, Oxfordu bądź Cambridge. Program ich edukacji w dużej mierze opierał się na autorach klasycznych ${ }^{20}$. Ich światopogląd kształtowano na podstawie prac Tytusa Liwiusza i dziejów imperium rzymskiego. Wojny Rzymu były ich wojnami, utożsamiali się z Cezarem, nie z Wercyngetoryksem. Rzymską virtus uważali za cnotę i chcieli ją pielęgnować w sobie. Spiskujący przeciwko własnemu państwu Katylina jawił się jako archetyp najgorszego typu wroga. Posiadanie imperium było faktem, którego sensu nikt nie negował. Elita imperialna dyskutowała nad sposobem rządzenia podległymi terenami, a nie nad sensem ich utrzymywania. Wszak Rzymianie nie podawali w wątpliwość sensu własnych podbojów.

Ponieważ większość spośród członków brytyjskiej elity imperialnej wywodziła się z arystokratycznych środowisk, obca była im mentalność „pogoni za groszem”. Przekazywane z pokolenia na pokolenie bogactwa stawiały ich w dość komfortowej sytuacji ekonomicznej. Dzięki temu mogli się poświęcić uprawianiu polityki, nie koncentrując się na zarabianiu na swe utrzymanie. Nie powinno zatem dziwić, że kładli tak duży nacisk na sprawę prestiżu ${ }^{21}$. Rządzone przez nich imperium musiało być wielkie i okryte chwałą. Podejście to wynikało z wykształcenia, jakie otrzymywali - swoistej mieszanki antycznych autorów i współczesnych im mitów imperialnych.

Za archetypową postać brytyjskiego oficera na Północno-Zachodnim Pograniczu Indii Brytyjskich można uznać Johna Nicholsona. Urodził się w 1821 roku, a przygodę z Pograniczem rozpoczął od pierwszej wojny afgańskiej. Potem brał udział w obu kampaniach przeciwko Sikhom, by od 1849 roku zaangażować się w organizowanie brytyjsko-afgańskich relacji na Pograniczu. Zginął bohaterską śmiercią na polu walki, mając 35 lat, w czasie tłumienia powstania sipajów (1857). Wiktoriańska historiografia przedstawiała go jako rycerza bez skazy, który niczym Święty Jerzy przybywa z odsieczą i walczy ze smokiem (w tym przypadku byli to zbuntowani Indusi). Jego dziewiętnastowieczne biografie są na wskroś hagiograficzne ${ }^{22}$. Sposób opisywania jego życia ${ }^{23}$, poświęconego służbie imperium, powielali biografowie innych imperialnych „świętych”, na przykład Henry'ego Lawrence'a ${ }^{24}$ lub Henry'ego Havelocka ${ }^{25}$. Żywotność tego mitu podtrzymywały także autobiografie ludzi służących na tych pogranicznych peryferiach, czego przykładem jest twórczość Roberta

19 Z. Najder, Wstęp [w:] J. Conrad-Korzeniowski, Wybór prozy, Wrocław 2015, s. LXXXLXXXIII.

20 R. Hyam, Understanding the British Empire, Cambridge 2012, s. 72-73.

21 D. Cannadine, Ornamentalism: How Britains Saw Their Empire, London 2001, s. 20-35.

22 Ch. Allen, Soldier Sahibs: The Men Who Made the North-West Frontier, London 2000, s. 5-6.

23 L. Trotter, Life of John Nicholson: Soldier and Administrator, London 1897.

24 H. Merivale, Life of Sir Henry Lawrence, London 1872.

25 J. Kay e, Lifes of Indian Officers, vol. I-II, London 1867. 
Warburtona $^{26}$. Drugą obok historyków grupą ludzi pióra, która wpłynęła na wytworzenie się heroicznego etosu, byli literaci.

Największy spośród imperialnych mitotwórców to Rudyard Kipling. George Orwell wskazywał, że Kiplingowski przypadek jest niezwykły, gdyż przez kilka literackich pokoleń oświeceni ludzie gardzili jego twórczością, ale summa summarum dziewięciu na dziesięciu spośród tych oświeconych zostało już zapomnianych, podczas gdy pamięć o Kiplingu i jego utworach wciąż pozostaje żywa ${ }^{27}$. Laureat literackiej Nagrody Nobla z 1907 roku poruszał tematykę pogranicza, tego swoistego mikrokosmosu, w swoich powieściach (m.in. $\mathrm{Kim}^{28}$ ), a także opowiadaniach (m.in. Plain Tales from the Hills ${ }^{29}$, The Man Who Would Be a King ${ }^{30}$ ). Jak zauważa Edward Said, Kiplingowska wizja Indii jest jednowymiarowa, gdyż autor ten dostrzega jedynie politykę imperialnego centrum ${ }^{31}$. Tworzone przez niego mity za swoje może przyjąć tylko kolonizująca strona tej relacji. Bohaterski mit pogranicza nie jest mitem Indusów, ale dzielnych młodych Brytyjczyków ${ }^{32}$.

Tytułowy Kim to człowiek z pogranicza dwóch światów. Mimo że ma białą skórę (jego ojciec był Irlandczykiem), jako sierota wychowuje się wśród wielorasowego społeczeństwa Lahore. Proces jego wchodzenia w dorosłość polega na podróży u boku tybetańskiego mnicha na odległe rubieże Indii, w czasie której poznaje, czym są poświęcenie dla imperium, męstwo, prawdziwa przyjaźń. Kipling wplótł w scenerię tego imperialnego mitu popularne od stuleci w literaturze angielskiej motywy pielgrzymowania, obecne w dziełach Geoffreya Chaucera czy Johna Bunyana ${ }^{33}$. Przesłanie ideowe tego mitu wydaje się jasne. Po pierwsze, służba na rzecz imperium nobilituje, gdyż wyrzutek społeczny dzięki swej dzielności zostaje doceniony przez imperium, któremu służy. Po drugie, taki jednostkowy przypadek ma też istotne znaczenie dla brytyjskiego panowania w Indiach, czyli, ujmując to bardziej poetycko, do dźwigania brzemienia białego człowieka.

Twórczość Kiplinga to literacka fikcja, ale jednocześnie kreuje ona rzeczywistość, co zauważali już jemu współcześni. George Younghusband, brytyjski oficer mający za sobą wieloletnią służbę w różnych imperialnych placówkach, wspomina o wzajemnym przenikaniu się mitu ze światem realnym. Podaje on, że żołnierze w różnych imperialnych garnizonach zachowywali się i używali podobnych słów jak bohaterowie dzieł autora Księgi dżungli, że to właśnie Kipling stworzył archetyp

26 R. Warburton, Eighteen Years in the Khyber, 1879-1898, London 1900.

27 G. Orwe1l, Kipling [w:] idem, Essays, London 2000, s. 203-204.

28 R. Kipling, Kim, tłum. J. Birkenmajer, Warszawa 2009.

29 Idem, Plain Tales from the Hills, Oxford 2009.

30 Idem, The Man Who Would Be a King, Oxford 2008. Utwór ten został zekranizowany w 1975 r., a w rolach głównych wystąpili znani brytyjscy aktorzy: Sean Connery i Michael Caine. W rolę Rudyarda Kiplinga wcielił się kanadyjski gwiazdor Christopher Plummer.

31 E. Said, Kultura i imperializm, tłum. M. Wyrwas-Wiśniewska, Kraków 2009, s. 40.

32 Więcej na temat sensu imperium w koncepcji Rudyarda Kiplinga w: D. Gilmour, The Long Recessional: The Imperial Life of Rudyard Kipling, London 2003, s. 70-83.

33 E. Said, op. cit., s. 147-172. 
Tommy'ego Atkinsa ${ }^{34}$ (mianem tym popularnie określa się stereotypowego brytyjskiego żołnierza).

Pogranicze było miejscem, w którym trubadurzy brytyjskiego imperium mogli umieścić akcje swoich powieści, żeby w jego scenerii przywołać mit bohaterski, niezbędny do ukształtowania w brytyjskim społeczeństwie imperialnych postaw. Rozpoczętą przez Johna Ruskina tendencję do przedstawiania wojen kolonialnych w kategoriach quasi-krucjat, walki w obronie słusznej sprawy, czyli cywilizacji, kontynuowali literaci, czego najlepszym przykładem jest twórczość Rudyarda Kiplinga.

Ów bohaterski mit imperialny miał wytworzyć pewien model zachowania, który świadomie mieli przyjmować ludzie zainteresowani w imperialnym przedsięwzięciu. Każde imperium musi zawierać w sobie pewien „sakralny” pierwiastek, a zmitologizowani bohaterowie wojen kolonialnych to imperialni święci, których „kanonizacji” dokonała „hagiograficzna” literatura czasów wiktoriańskich. Była to jedna strona medalu.

\section{POGRANICZE JAKO LABORATORIUM WOJENNYCH TECHNOKRATÓW}

Oprócz bycia imperialnym mitem (funkcja idealistyczna) Północno-Zachodnie Pogranicze Indii Brytyjskich odgrywało też inną, równie istotną rolę. Stało się ono swego rodzaju poligonem doświadczalnym, na którym testowano nowy sposób prowadzenia wojny. Ponieważ konflikt na granicy indyjsko-afgańskiej stanowił inny typ zmagań militarnych niż to, czego armia królowej Wiktorii doświadczyła w czasie wojny krymskiej czy walk na indyjskich równinach, odmienne musiało być także podejście do niego. Brytyjczycy zdali sobie z tego sprawę na początku lat 90 . XIX wieku. Pod koniec tej dekady mieli już opracowane teoretyczne aspekty tego typu konfliktu zbrojnego, konfliktu, który przez współczesną nomenklaturę wojskową określany jest mianem ,asymetrycznego”.

Pojawienie się takiej refleksji to pochodna zmiany podejścia do wojny cechującej się swoistą „technokratyzacją”, jak również doświadczeniem walk na samym Pograniczu. Od połowy lat 80. XIX stulecia, zamiast dawnych luźnych i na wskroś paramilitarnych oddziałów, cyklicznie angażowano tam regularne jednostki armii brytyjskiej.

Zmiany organizacyjne w samej armii polegały na wprowadzeniu bardziej racjonalnego, opartego na wymiernych przesłankach sposobu zarządzania oddziałami. To zaś w połączeniu z doświadczeniami walk z plemionami pasztuńskimi na Pograniczu oznaczało technokratyzację konfliktu asymetrycznego. Romantyczna wizja dzielnego herosa, który przy użyciu honorowej białej broni walczy z napierającymi barbarzyńcami, miała zostać zastąpiona podejściem „naukowego” rozpracowania wroga i zniszczenia go przy jak najmniejszych stratach własnych.

34 G. Younghusband, A Soldier's Memories in Peace and War, London 1917, s. 187-188. 
Największym konfliktem, w który zaangażowała się armia brytyjska do 1914 roku, były wojny napoleońskie. W dużym uproszczeniu można powiedzieć, że pomimo pewnego nowatorstwa wprowadzonego do sztuki wojennej przez cesarza Francuzów opierały się one na archaicznym schemacie - wiele zależało od genialnego wodza i podjętych przez niego decyzji. Zbyt mocno uzależniało to armie od predyspozycji ich dowódców. Ponieważ bitwę pod Waterloo wygrały oparte na tym modelu oddziały Wellingtona, a sama Wielka Brytania przez kilka dziesięcioleci nie musiała bezpośrednio angażować się w walki na Starym Kontynencie, zaniechano prac związanych z modernizacją armii na Wyspach. Istotna tu była także zachowawcza postawa Księcia Cambridge, członka rodziny królewskiej, który jako głównodowodzący armią brytyjską przez niemal całą drugą połowę XIX stulecia skutecznie blokował wszelkie próby wprowadzenia innowacji.

Odmienne były losy armii pruskiej, która jako pierwsza przeprowadziła rewolucję technologiczną. Oprócz mniej istotnych dla badanego problemu zmian w zakresie sposobu rekrutacji żołnierzy dokonano także modyfikacji samego podejścia do administrowania wojskiem, co w praktyce oznaczało zmniejszenie roli genialnego wodza, samodzielnie obmyślającego plany kampanii, na rzecz kolegialnych sztabów głównych. To tam, wykorzystując najnowsze osiągnięcia inżynierii i kartografii, zespół ludzi już w czasie pokoju opracowywał plany na wypadek wojny ${ }^{35}$. Doświadczenia płynące zza oceanu, gdzie w latach 60. XIX wieku toczyła się wojna secesyjna, pierwsza wojna epoki przemysłowej, wskazywały, że jeden człowiek, choćby najgenialniejszy, nie jest już w stanie sam stawić czoła wszystkim wyzwaniom, jakie niesie ze sobą nowy typ konfliktu zbrojnego.

Przy planowaniu wojny dokonywano rozróżnienia przeciwników ze względu na ich potencjał i specyfikę ich armii. Żeby tego dokonać, należało zebrać jak najwięcej wiarygodnych danych na temat wroga. Doceniono znaczenie informacji przy planowaniu strategicznym: należało mieć jak największą ilość wiarygodnych danych. Przy sztabie głównym pojawiły się departamenty wywiadu. Miały one za zadanie zbierać i przetwarzać dane, na podstawie których można było poznać modus operan$d i$ wroga $\mathrm{i}$ w stosunku do niego ustalić plany działania w przypadku ewentualnego konfliktu zbrojnego. Równolegle z departamentami odpowiedzialnymi za zbieranie danych powstało też stanowisko attaché wojskowego, na bieżąco przyglądającego się armiom w miejscu swojego przydziału.

Powołanie sztabu głównego i departamentu wywiadu stanowiło rezultat nowego, „technokratycznego" podejścia do wojny. Aby miało ono sens, należało też zmienić sposób szkolenia oficerów niższego szczebla, którzy w terenie mieli wcielać w życie decyzje sztabowców. Skoro wojna stawała się coraz bardziej uprzemysłowiona, używany sprzęt coraz bardziej zaawansowany, a wzajemna relacja między poszczególnymi typami wojsk coraz bardziej skomplikowana, nie wystarczało już hołdować heroicznym cnotom rodem z Homera. Owszem, to nadal było ważne ze względu na motywację poszczególnych oficerów, ale jeszcze ważniejsze okazało się techniczne przygotowanie do wyzwań, jakie stawiało nowe pole walki. Powołano więc

35 M. How ard, Wojna w dziejach Europy, tłum. T. Rybowski, Wrocław 2007, s. 105-126. 
Królewską Akademię Wojenną w Woolwich. To ta placówka miała się okazać kuźnią nowej wojskowej „technokratycznej elity”, która zmieni podejście także do konfliktów asymetrycznych na imperialnych pograniczach ${ }^{36}$.

Zmiany zachodzące w samej Wielkiej Brytanii nie ominęły Indii Brytyjskich i ich armii. Dotychczasowy model wspólistnienia niezależnych wojsk trzech prezydencji, co samo w sobie było spuścizną po czasach rządów Kompanii, stopniowo ulegał przekształceniu. W 1895 roku wojska prezydencji połączyły się w jedną armię indyjską pod jednolitym dowództwem. W 1903 roku głównodowodzącym armią indyjską został Lord Kitchener. Zakończył on wieloletni proces modyfikacji podlegającego Indian Office wojska. Quasi-żandarmeria broniąca Brytyjczyków przed mogącymi się zbuntować Indusami zmieniła się w wojsko mające chronić British Raj przed głównym zewnętrznym wrogiem, za którego do 1907 roku uważano carską Rosję ${ }^{37}$.

Wizja rosyjskiej inwazji na Indie rozgrzewała umysły Brytyjczyków od początku XIX stulecia. Wielu śmiałków na służbie czy to Kompanii, czy Korony wędrowało na odległe rubieże, aby empirycznie zweryfikować pogłoski o rosyjskiej penetracji tych terenów. Ze swoich podróży spisywali relacje czytane i wykorzystywane przez przedstawicieli kolejnych generacji. Prowadzone w ten sposób badania pogranicza miały zbyt indywidualistyczny i nieskoordynowany charakter. Technokratyzacja armii brytyjskiej niosła ze sobą także większą systematykę w gromadzeniu, przetwarzaniu i przechowywaniu danych na temat miejscowego wroga.

Od lat 70. XIX wieku istniał współpracujący z londyńską centralą departament wywiadowczy w Simli. Jego głównym zadaniem było zbieranie informacji na temat Pogranicza i czyhających tam wrogów ${ }^{38}$. Ponieważ jedynym nieprzyjacielem związanym z tym regionem, którego dało się „policzyć i zmierzyć” jako tradycyjnego, symetrycznego wroga, była carska Rosja, wywiad zaczął produkować raporty na temat stanu garnizonów w Turkiestanie ${ }^{39}$, tempa i kierunku rosyjskiej ekspansji terytorialnej ${ }^{40} \mathrm{i}$, co równie ważne, stosunku tubylców zarówno do Rosji, jak i do Wielkiej Brytanii ${ }^{41}$. Ponadto zaczęto thumaczyć rosyjskie raporty dotyczące spraw Azji

36 J. Hevia, The Imperial Security State: British Colonial Knowledge and Empire-Building in Asia, Cambridge 2015, s. 43-52.

37 Więcej na temat zmian, jakie w indyjskiej armii przeprowadzono na przełomie XIX i XX w. zob. w: T.A. Heathcote, The Army of British India [w:] The Oxford History of the British Army, ed. D.G. Chandler, Oxford 2003, s. 362-384.

38 J. Hevia, op. cit., s. 65-72.

39 DMO/13/6: Report upon the Military Situation in Transcaspia. 20 th January 1886. Prepared in the Intelligence Branch, War Office by Captain J. Wolfe Murray, R.A., D.A.Q.M.G. London: Printed at the War Office, by Harrison \& Sons, 1886.

$40 \mathrm{DMO} / 13 / 3$ : Analysis of General Kuropatkin's Scheme for the Invasion of India. By J.M. Grierson, Captain, R.A.

${ }_{41}$ DMO/13/12: Report of a Trip through Transcaspia and Turkestan in October, 1888. By Colonel the Hon. R.A.J. Talbot, C.B., with marginal notes prepared in the Intelligence Division, War Office. London: Printed at the War Office, by Harrison and Sons, 1889, s. 6-7. 
Środkowej ${ }^{42}$. Innymi słowy, sprofesjonalizowano zbieranie danych i wykorzystywanie ich w planowaniu wojskowym.

Owa pierwsza faza rewolucji militarnej w strukturach armii brytyjskiej dotyczyła głównie konfliktów z regularnym wrogiem, zorganizowanym w podobny sposób jak Wielka Brytania. O co najmniej pokolenie później przyszła zmiana podejścia do konfliktu asymetrycznego. Aby do tego doszło, regularna armia brytyjska musiała dotrzeć na Pogranicze, wziąć na siebie główny ciężar walk z niespokojnymi Pasztunami i wykorzystać przeciwko nim wnioski płynące z technokratyzacji pola bitwy.

Ze specyfiką asymetrycznej walki na Pograniczu brytyjscy wojskowi po raz pierwszy zetknęli się w czasie pierwszej wojny afgańskiej (1839-1842). Gładko pokonano quasi-regularne afgańskie oddziały i zajęto stolicę, ale po buncie mieszkańców Kabulu armia bengalskiej prezydencji musiała w nieładzie wycofać się na swoje indyjskie pozycje. W tym czasie nękana była przez afgańskich partyzantów, co zakończyło się katastrofą. Ponieważ wojna afgańska nie niosła ze sobą trwałych zdobyczy terytorialnych, trzeba było czekać prawie 10 lat na bezpośrednie zaangażowanie się Brytyjczyków w sprawy Pogranicza. Wygrywając w 1849 roku tak zwaną drugą wojnę sikhijską, do British Raj przyłączono cały Pendżab i podległe mu afgańskie terytoria. To właśnie od tego momentu datuje się początek Północno-Zachodniego Pogranicza Indii Brytyjskich.

Aby bronić pendżabskich równin przed nacierającymi z gór Pasztunami, powołano podległą Radzie Administracyjnej Pendżabu jednostkę Punjab Irregular Forces (PIF). Do 1886 roku ten oddział, który później (1867) przekształcono w Punjab Frontier Forces (PFF), był strukturalnie niezależny od indyjskiej armii. Zorganizowali go sir Henry Lawrence i porucznik Henry Lumsden. Kadrę oficerską stanowili Brytyjczycy zdobywający doświadczenia zarówno w pierwszej wojnie afgańskiej, jak i w wojnach sikhijskich. Podobną formę miały inne nieregularne jednostki powołane w tym czasie, na przykład Corps of Guides czy dowodzona przez legendarnego Roberta Warburtona, powołana w 1878 roku jednostka Khyber Riffles.

Zadania PIF vel PFF w zasadzie ograniczały się do patrolowania i bronienia pendżabskich równin przed górskimi koczownikami. Warto także nadmienić, że PIF to pierwsza jednostka w historii brytyjskiej armii, którą wyposażono w mundury w kolorze khaki (1853). Można w tym zauważyć wpływ doświadczeń walk na Pograniczu na strukturę organizacyjną oddziału. Maskujące barwy były bardziej adekwatne do teatru działań. Aby przeżyć, należało tam stosować mniej konwencjonalne metody.

Kamieniem milowym w dziejach brytyjskiego zaangażowania militarnego na Pograniczu okazała się druga wojna afgańska (1878-1879). Żołnierze PFF, mający doświadczenie w walkach na tamtych terenach, prezentowali się w trakcie zmagań znacznie lepiej niż konwencjonalna armia indyjska, co sprawiło, że wielu wojskowych zaczęło rozważać zmianę metod szkolenia. Dostrzeżono, że walki na imperialnych

42 DMO/13/2: Affairs in Turkestan. Compiled by Colonel Belayevsky of the Russian General Staff. Translated in the Intelligence Branch, War Office, under the supervision of Captain J.W. Murray, D.A.Q.M.G. with a Preface by Major-General H. Brackenbury, C.B. London: Printed at the War Office, by Harrison \& Sons, 1886. 
rubieżach wymagają innego podejścia taktycznego i logistycznego ${ }^{43}$. Zmianom W wojskowej mentalności towarzyszyły zmiany organizacyjne. W 1886 roku nieregularne oddziały PFF zostały włączone w struktury armii indyjskiej. Zadania do tej pory wykonywane przez lokalne pendżabskie jednostki stały się udziałem regularnych brytyjskich oddziałów.

W latach 80. XIX stulecia w brytyjskiej prasie wojskowej zaczęły się ukazywać artykuły „technokratycznych” oficerów (przeważnie wyszkolonych w RMA w Woolwich). Analizując problemy w wojnach kolonialnych (oprócz walk na Pograniczu brano pod lupę także południowoafrykańskie zmagania z Zulusami i sudańskie z mahdystami), lansowali oni zmiany w podejściu do tak zwanej savage warfare wojny z dzikusami, czyli przeciwnikami niezorganizowanymi w europejskim stylu.

Za przełomowy należy uznać artykuł kapitana Charlesa Callwella, opublikowany w 1887 roku na łamach „Journal of the Royal United Service Institution”. Prezentował on wnioski z wojen kolonialnych, ze szczególnym uwzględnieniem walk na Pograniczu. Artykuł ten ugruntował pozycję Caldwella jako specjalisty od savage wars. Jego opus magnum były wydane w 1896 roku, a później wznawiane Small Wars $^{44}$ - pierwszy kompletny, fachowy i mający duży wpływ na zmianę taktyki wojennej podręcznik dla oficerów o prowadzeniu walk na pograniczu ${ }^{45}$. Autor omawiał aspekty taktyczne oraz sposób, w jaki należy traktować tubylców, by wykonać zadanie (tj. rozbić partyzanckie oddziały wroga). Callwell przedstawiał cele prowadzenia „małych wojen”, rolę wywiadu i kwestię odpowiedniego zadbania o linie komunikacyjne. W przeciwieństwie do „cywilizowanych wojen”, będących walkami przeciwko liczbie, „małe wojny” były przede wszystkim wojnami przeciwko naturze, a więc trudnościom wynikającym z ukształtowania terenu, na który dokonuje się inwazji. Small wars są wojnami stricte imperialnymi. To zmagania centrum i zbuntowanej peryferii. Omawiana praca nie jest moralnym traktatem usprawiedliwiającym takie wojny, lecz „technokratycznym” podręcznikiem dającym wskazówki, jak poradzić sobie z zaistniałym problemem ${ }^{46}$.

Sam Callwell, jak trafnie określa to James Hevia, został ukształtowany przez zreformowany w Wielkiej Brytanii w latach 70. XIX wieku program szkolenia oficerów. Absolwent RMA w Woolwich miał praktyczne przygotowanie do podjętego przez siebie zadania. Będąc weteranem drugiej wojny afgańskiej, doświadczywszy na własnej skórze, czym jest wojna na Pograniczu, jako wojskowy doktryner łączył w sobie solidne teoretyczne (,technokratyczne”) i praktyczne przygotowanie. W 1887 roku rozpoczął służbę w dziale wywiadu War Office. Ukoronowaniem jego kariery było objęcie funkcji szefa wywiadu wojskowego tuż przed I wojną światową, gdy miał już stopień generała majora ${ }^{47}$.

43 T.R. Moreman, The Army in India and the Development of the Frontier Warfare, 1849-1947, London 1998, s. 38-40.

${ }_{44}$ Ch.E., Callwell, Small Wars: Their Principles and Practice, $2^{\text {nd }}$ ed., London 1906.

45 Ibidem, s. 21-22.

46 J. Hevia, op. cit., s. 217-222.

47 Ibidem, s. 216-217. 
Pojawiła się teoretyczna refleksja nad specyfiką nowego typu wojny, ale musiała minąć kolejna dekada, żeby dowództwo zaczęło stosować się do rad Callwella i jemu podobnych. Przykre dla Brytyjczyków doświadczenia wojenne lat 90. XIX stulecia, to jest powstanie w Waziristanie (1894-1895), walki o Czitral (1895) czy przede wszystkim ekspedycja do Tirahu, ostatecznie dowiodły konieczności zmian. Dowodzone przez sir Williama Lockharta Tirah Expedition Forces (TEF), mimo że były najliczniejszą i najlepiej uzbrojoną armią na Pograniczu od czasów drugiej wojny afgańskiej, poniosły duże straty w walkach z Pasztunami. Wynikały one głównie ze złej organizacji i oderwania doktryny wojennej od realiów górskiego placu boju. Zakończenie ekspedycji zaowocowało podjęciem na nowo debaty o small wars. Dowództwo tym razem postanowiło wyciągnąć wnioski i na serio zastosować się do proponowanych przez Callwella zmian ${ }^{48}$.

Jedną $\mathrm{z}$ łatwo zauważalnych modyfikacji w szkoleniu, stanowiących pokłosie ekspedycji do Tirahu, było utworzenie i wyszkolenie większej liczby batalionów, tak zwanych scoutów. Istniejące wcześniej tego typu jednostki (swoiste prefiguracje późniejszych oddziałów specjalnych), złożone głównie z Gurków, dowiodły swojej skuteczności w walkach z lat 1897-1898.

Realizacją Callwellowych rad była także reforma armii indyjskiej przeprowadzona na początku XX stulecia przez Kitchenera. Do jej istotnych elementów należało rotacyjne przesuwanie jednostek z równin na Pogranicze. Tam uczyły się one nowych metod prowadzenia wojny i miały kontakt $\mathrm{z}$ prawdziwym wrogiem ${ }^{49}$.

Za zakończenie pewnej epoki zmagań na Pograniczu można uznać decyzje mianowanego w 1898 roku wicekróla Indii, lorda Curzona. Markiz Kedleston, znany ze swoich geopolitycznych poglądów na temat Rosji i jej celów w Azji, twierdził, że państwo carów jest głównym niebezpieczeństwem dla Indii Brytyjskich. W celu ich ochrony Indian Army nie powinna marnować potencjału na walki z Pasztunami, do czego dochodziło w czasie ekspedycji do Tirah. W koncepcji Curzona konfliktom miało zapobiec lepsze ułożenie relacji z afgańskimi plemionami. W tym celu powinno się im dać pewną formę autonomii. W 1901 roku z terytoriów podległych do tej pory władzom Pendżabu utworzono North-West Frontier Province (NWFP). Oznaczało to wycofanie brytyjskich garnizonów z tej części Pogranicza ${ }^{50}$. W ramach zmian wprowadzonych w zarządzaniu oficjalnie rozwiązano PFF jako oddzielną jednostkę w strukturach armii brytyjskiej (1903). Można powiedzieć, że było to symboliczne zamknięcie pewnej epoki w podejściu do wojny na tym obszarze.

Wnioski płynące z walk na Pograniczu zawarte w dziele Callwella zaowocowały także pogłębioną refleksją na temat specyfiki asymetrycznych konfliktów kolonialnych w innych częściach imperium brytyjskiego. W 1906 roku w instrukcjach dla oficerów pojawiły się poradniki, jak prowadzić walki na innych ekstremalnych terenach (tj. w buszu, w dżungli, na pustyni).

48 T.R. Moreman, op. cit., s. 72-73.

49 Ibidem, s. 88-89.

50 S. Bangash, The Frontier Tribal Belt: Genesis and Purpose under the Raj, Oxford 2016, s. 184-195, zob. też: C. Collin Davies, The Problem of the North-West Frontier, 1890-1908, Cambridge 1932, s. 99-115. 
Praktycznym sprawdzianem efektywności zmian w szkoleniu oficerskim, które lansowali Callwell i jemu podobni, stały się wydarzenia w 1908 roku. Tak zwana operacja Zakka Khel dowiodła, że nowe, „technokratyczne” podejście do konfliktów asymetrycznych jest korzystne z punktu widzenia imperialnego centrum. Dowodzone przez sir Jamesa Willcocksa oddziały przy niewielkich stratach własnych pokonały zbuntowanych Pasztunów. Powszechne przyjęcie „naukowego” podejścia do walk przyniosło wymierne rezultaty ${ }^{51}$.

Najważniejszą lekcją, jaką brytyjskie władze wojskowe wyciągnęły z wydarzeń na Pograniczu z przełomu XIX i XX wieku, okazało się dominujące przekonanie o wartości informacji na temat przeciwnika. Znając jego modus operandi i wiedząc, jak jest uzbrojony, można było dostosować własną taktykę do taktyki wroga. Warte podkreślenia wydaje się to, że brytyjscy wojskowi mieli także świadomość zmian w zachowaniu Pasztunów. Oni też wyciągali lekcję z przeszłości i dzięki przemytowi broni uzbrajali się w coraz skuteczniejsze karabiny. Przekonanie o ciągłym poznawaniu wroga i adaptacji własnych metod walki do jego metod było najważniejszą lekcją, którą technokraci odrobili na Pograniczu.

Brytyjczycy byli zaangażowani w walki aż do 1947 roku, do samego końca Indii Brytyjskich. Reagując na zmianę warunków prowadzenia wojny, wykorzystywali coraz nowszy sprzęt, czego najjaskrawszym przykładem jest użycie samolotów w czasie trzeciej wojny afgańskiej (1919). Wojna nie była już tylko powieleniem imperialnego mitu bohaterskiego, stała się miejscem pracy dla wojskowego „technokraty”. Obserwował on, mierzył, gromadził i analizował informacje, a następnie na tej podstawie podejmował działania.

\section{PODSUMOWANIE}

Północno-Zachodnie Pogranicze Indii Brytyjskich było najniebezpieczniejszą i najtrudniejszą lądową granicą imperium brytyjskiego. Terytorium, na którym Brytyjczycy na dobre pojawili się w połowie XIX wieku, stanowiło duże wyzwanie. Musiało mu stawić czoła kilka pokoleń brytyjskiej klasy imperialnej. Ponieważ imperium to bilateralna relacja centrum-peryferia, nie dziwi fakt, że Pogranicze odcisnęło swe piętno na brytyjskiej wizji imperium na przełomie XIX i XX wieku.

Pogranicze wpłynęło na refleksję imperialną przez dwa oddzielne kanały, roboczo nazwane ,idealistycznym” i „technokratycznym”. Było imperialnym mitem Wielkiej Brytanii, co zdefiniowano jako specyficzną interpretację przeszłości, która wydarzeniom historycznym nadała rangę bezczasowych wzorców postępowania. Kształtowały one tożsamość brytyjskich elit imperialnych. Pełne romantycznego wdzięku literackie przedstawienie wojen kolonialnych jako quasi-krucjat w obronie cywilizacji oddziaływało na mentalność brytyjskich elit. Wykreowano wizję, w której mieszkaniec zindustrializowanych Wysp mógł opuścić pełen pary i stali świat

\footnotetext{
51 T.R. Moreman, op. cit., s. 89-92.
} 
w poszukiwaniu prawdziwej przygody, aby dowieść swego męstwa. Jak w klasycznym campbellowskim modelu odległe, pełne niebezpieczeństw krainy okazywały się miejscem, gdzie bohater odnajdował zgubione przez jego wspólnotę wartości.

Pogranicze miało też swój „,technokratyczny” wymiar. To tam wyszkoleni w Woolwich według nowych standardów oficerowie mogli zbierać materiały i wykazywać, jak z technicznego punktu widzenia powinno się prowadzić wojnę z „dzikusami”. Jak przy minimalnych stratach własnych realizować zamierzone cele. Takie rozumowanie opierało się na schemacie: ,jest problem, należy go naukowo zbadać”, czyli zebrać niezbędne informacje i na tej podstawie opracować rozwiązanie.

Podsumowując rozważania nad wpływem Pogranicza na brytyjską wizję imperium na przełomie XIX i XX wieku, należy stwierdzić, że był to dynamiczny i niezwykle interesujący okres. Wówczas ujęto w solidne teoretyczne ramy problemy doskwierające od wielu dekad. Imperialny mit bohaterski istniał od dawna, ale to w twórczości Kiplinga osiągnął swoje apogeum. Powieści laureata literackiej Nagrody Nobla wpisywały się w schemat przedstawiania żywotów imperialnych bohaterów, popularny na przełomie stuleci.

Podobnie było $\mathrm{z}$ technokratycznym podejściem do wojny. Informacje na temat Pogranicza i rosyjskiej penetracji terenów leżących poza nim zbierano od dawna, ale robiono to niesystematycznie. Od lat 70. XIX wieku proces ten ustandaryzowano. Swego rodzaju ukoronowaniem tych działań stało się zastosowanie na początku XX wieku rad, które wypływały z Callwellowych Small Wars. W tym znaczeniu wojna na pograniczu przestała być romantyczna, gdyż wdarła się do niej cyniczna kalkulacja.

Oba kanały istniały równolegle. Imperialny mit bohaterski i sens imperialnego poświęcenia zostały nieco podkopane przez doświadczenia I wojny światowej, by całkowicie stracić na znaczeniu po 1945 roku. Obie wojny światowe toczono według schematów opracowanych przez ludzi pokroju Charlesa Callwella, tyle że na większą skalę, przeciwko rzekomo cywilizowanemu wrogowi. Książka Small Wars stanowiła inspirację także dla ludzi żyjących w drugiej połowie XX wieku. Wszak Brytyjczycy stosowali się do rad Callwella podczas tłumienia powstania w swoich zbuntowanych koloniach, na przykład na Malajach czy w Kenii. Z rad oficera brytyjskiego wywiadu korzystali też Amerykanie w Wietnamie.

Mając to na uwadze, można stwierdzić, że „technokratyczny” wpływ Pogranicza na brytyjską wizję imperium był długotrwały i nie ograniczał się do samego imperium brytyjskiego. Asymetryczne konflikty zbrojne są zmorą mocarstw naszych czasów. Tereny, na których się toczą, pewien niemiecki uczony nazwał ,imperialną granicą barbarzyńską" ${ }^{52}$. Różnica między obecną sytuacją a tą sprzed ponad 120 lat jest taka, że w tej chwili nikt nie przedstawia tych walk w kategoriach quasi-hagiograficznych. Imperialna narracja i imperialne mity bohaterskie nie przemawiają już do wyobraźni ludzi Zachodu jak w czasach wiktoriańskich. Opinia publiczna coraz częściej sympatyzuje z dzielnymi Czeczenami, mudżahedinami czy Kurdami, walczącymi z imperialną agresją. Niewiele zmieniły się tylko metody walk. Agresorzy prowadzą swoje

52 H. Munkler, Wojny naszych czasów, thum. K. Matuszek, Kraków 2003. 
działania zbrojne według zasad naszkicowanych w Small Wars. Z perspektywy czasu można zaryzykować postawienie tezy, że z dwutorowego wpływu Pogranicza na brytyjską wizję imperium i porządku na świecie Callwell zatryumfował nad Kiplingiem, technokraci nad romantykami.

\section{BIBLIOGRAFIA}

\section{Archiwa}

Indian Office Record. British Library, London

DMO/13/2: Affairs in Turkestan. Compiled by Colonel Belayevsky of the Russian General Staff. Translated in the Intelligence Branch, War Office, under the supervision of Captain J.W. Murray, D.A.Q.M.G. with a Preface by Major-General H. Brackenbury, C.B. London: Printed at the War Office, by Harrison \& Sons, 1886.

DMO/13/3: Analysis of General Kuropatkin's Scheme for the Invasion of India. By J.M. Grierson, Captain, R.A., 1886.

DMO/13/6: Report upon the Military Situation in Transcaspia. $20^{\text {th }}$ January 1886. Prepared in the Intelligence Branch, War Office by Captain J. Wolfe Murray, R.A., D.A.Q.M.G. London: Printed at the War Office, by Harrison \& Sons, 1886.

DMO/13/12: Report of a Trip through Transcaspia and Turkestan in October, 1888. By Colonel the Hon. R.A.J. Talbot, C.B., with marginal notes prepared in the Intelligence Division, War Office. London: Printed at the War Office, by Harrison and Sons, 1889.

\section{Źródła narracyjne}

Beynon W.G.L., With Kelly to Chitral, London 1896.

Callwell T.E., Small Wars: Their Principles and Practice, $2^{\text {nd }}$ ed., London 1906.

Churchill W., Moja młodość, thum. T. Bieroń, Poznan 2000.

Kaye J., Lifes of Indian Officers, London 1867.

Kipling R., Kim, thum. J. Birkenmajer, Warszawa 2009.

Kipling R., Plain Tales from the Hill, Oxford 2009.

Kipling R., The Man Who Would Be a King, Oxford 2008.

Merivale H., Life of Sir Henry Lawrence, London 1872.

Orwell G., Kipling [w:] G. Orwell, Essays, Oxford 2010.

Robertson G.S., Chitral: The Story of Minor Siege, London 1900.

Thompson H.C., The Chitral Campaign, London 1895.

Trotter L., The Life of John Nicholson: Soldier and Administrator, London 1897.

Younghusband F.E., The Relief of Chitral, London 1895.

Younghusband G., A Soldier's Memories in Peace and War, London 1917.

Warburton R., Eighteen Years in the Khyber, 1879-1898, London 1900. 


\section{Opracowania}

Allen Ch., Soldier Sahibs: The Men Who Made the North-West Frontier, London 2000.

Bangash S., The Frontier Tribal Belt: Genesis and Purpose under the Raj, Oxford 2016.

Biernat T., Mit polityczny, Warszawa 1989.

Campbell J., Bohater o tysiącu twarzy, tłum. A. Jankowski, Kraków 2013.

Campbell J., Potega mitu. Rozmowy Billa Moyersa z Josephem Campbellem, thum. I. Kania, Kraków 1994.

Cannadine D., Ornamentalism: How Britains Saw Their Empire, London 2001.

Colin Davies C., The Problem of the North-West Frontier, 1890-1908, Cambridge 1932.

Gilmour D., The Long Recessional: The Imperial Life of Rudyard Kipling, London 2003.

Heath cote T.A., The Army of British India [w:] The Oxford History of the British Army, ed. D.G. Chandler, Oxford 2003.

Hevia J., The Imperial Security State: British Colonial Knowledge and Empire-Building in Asia, Cambridge 2015.

How ard M., Wojna w dziejach Europy, tłum. T. Rybowski, Wrocław 2007.

Hyam R., Understanding the British Empire, Cambridge 2012.

MacKenzie J., Heroic Myths of Empire [w:] Popular Imperialism and the Military, 18501950, Manchester 1980.

MacKenzie J., Introduction [w:] Popular Imperialism and the Military, 1850-1950, ed. J. MacKenzie, Manchester 1980.

Moreman T.A., The Army in India and the Development of the Frontier Warfare, 18491947, London 1998.

Munkler H., Wojny naszych czasów, tłum. K. Matuszek, Kraków 2003.

Najder Z., Wstęp [w:] J. Conrad-Korzeniowski, Wybór prozy, Wrocław 2015.

Paxman J., Empire, London 2012.

Said E.W., Kultura i imperializm, tłum. M. Wyrwas-Wiśniewska, Kraków 2009.

Siewierska-Chmaj A., Mity $w$ polityce. Funkcje $i$ mechanizmy aktualizacji, Warszawa 2016.

Słownik języka polskiego, t. 2, red. M. Szymczak, Warszawa 1979.

Stokes E.T., The Administrators and Historical Writings on India [w:] Historians of India, Pakistan and Ceylon, ed. H. Phillips, Oxford 1961

Szacka B., Czas przeszły, pamięć, mit, Warszawa 2006.

Szacka B., Pamięć spoteczna a identyfikacja narodowa [w:] Trudne sąsiedztwa. Z socjologii konfliktów narodowościowych, red. A. Jasińska-Kania, Warszawa 2001.

Trzciński Ł., Mit bohaterski w perspektywie antropologii filozoficznej i kulturowej, Kraków 2006.

Wielomski A., Mit polityczny [w:] Encyklopedia polityczna, t. 1: Myśl polityczna: główne pojęcia, doktryny i formy ustroju, red. J. Bartyzel, B. Szlachta, A. Wielomski, Radom 2007. 